\title{
Application of thermal discomfort indices for the coastal zone of Black Sea, in Dobrogea Region
}

\author{
Carmen Maftei, Constantin Buta
}

\begin{abstract}
The main goal of this paper is to establish the thermal comfort or thermal discomfort conditions for the coastal zone of Black Sea, in Dobrogea region (Romania). In the last century there have been many efforts to assess the degree of thermal discomfort and heat stress for different types of climates and taking into account as many climate variables. The thermal discomfort is difficult to be quantified because it is necessary to consider a range of environmental and human factors to decide what makes a person to feel thermal comfortable. This article is divided into three sections. First section presents the indices used in determining thermal discomfort, in the second section are presented: the main climatic characteristics of the Dobrogea region and the data and methods used in determining thermal discomfort indices. Section three is dedicated to results and discussion.
\end{abstract}

Keywords - thermal discomfort indices, climate change, air temperature, relative humidity, mathematical models

\section{INTRODUCTION}

Since the time of Herodotus $(430 \mathrm{dBC})$ is known that climate change affects human health (Nastos and Mastorakis, 2006). Reports of the various European professional organizations (EEA, IPPC) shows that global warming causes climate change expressed for example by the temperature increasing. In Europe, the increase in temperature in recent decades is $1.30 \mathrm{o}$, compared to the 1970-1990 period, especially in Southeast Europe (EEA, 2012). In recent years, the frequency and severity of heat waves has increased. Climate models forecast an increase in temperatures in South Eastern Europe with $2.5 \mathrm{oC}$ up to $4.0^{\circ} \mathrm{C}$ (EEA, 2012). Temperatures outside a comfort range affect the human health and are related to increased mortality. For example, the

Manuscript received: $5^{\text {th }}$ May 2017

Carmen Maftei - Ovidius University of Constanta, Bd. Mamaia nr. 124, 900356-Constanta, Romania (corresponding author phone: +40-241-619040; fax: +40-241-618372; e-mail: cemaftei@gmail.com) Constantin Buta - OvidiusUniversity of Constantza, Civil Engineering Faculty, Romania 
mortality rate (no. of deaths / 100,000 persons) in Southeast Europe due to extreme temperatures is 21 for the period 1980-2011 (source: EM-DAT, ESTAT, World Bank). In the summer of 2003 , considered the year with the highest temperatures by the experts, the number of people killed prematurely due to excessive temperatures was 70,000 people [20]. In these circumstances, knowledge of the conditions of thermal discomfort it is necessary, especially in areas with high mortality risk due to excessive temperatures. The thermal comfort is difficult to be quantified because it is necessary to consider a range of environmental and human factors to decide what makes a person to feel thermal comfortable. The factors that influence thermal comfort are classified into two categories: (i) environmental factors and (ii) so called "human" factors. In the first category are: air temperature, radiant temperature, wind speed and air humidity. In the second category are: so called "metabolic heat", means the heat produced by the body if the man would carry out physical activities, and as well clothing, here referring the required clothing insolation. If the first factors are directly measurable, the factors from the the second category require long-term experiments to be performed.

In the last century there have been many efforts to assess the degree of thermal comfort and heat stress. As a result there appeared a series of indices that can be divided into three categories ([18], Nish, 1986): (i) rational indices that are indices calculated based on thermal balance, for exemple: heat stress index [2]; (ii) empirical indices that are based on subjective and objective requests (i.e.:psychological indices), and (iii) direct indices that are based on direct measurement of the environmental variables, for exemple: apparent temperature (Steadman, 1984). The indices from the first two categories are difficult to be quantified because some of them depend on measurable variables which are difficult or requiring invasive methods of measurement. Taking into account the recommendations of ISO no.1526532, d'Ambrosio Alfano (2010) [5] brings together all thermal comfort indices into three categories according to the climate types: cold, moderate and excessively hot. $\mathrm{He}$ specifies the thermal comfort indices which are suitable for use for each of the three categories of environmental conditions. Most of the indices specified are those listed above as direct indices.

Although, from the chronological point of view, the first index from the direct indices category is introduced by Hill in 1916 [8], the best known is calculated by Thom (1959) [24]. This index is calculated based only on the measured temperatures with the wet and dry thermometer and it is called discomfort index (DI). Since the temperature measured at the wet thermometer is not always available to researchers, and because it can be determined on the basis of the relative humidity ( $\mathrm{RH}$ ), this indicator it is known as the temperature humidity index (THI). Another known index is the one determined by Missenard (1933) [15]. This index, called the effective temperature index (TEE) establishes a link between the body's thermoregulatory capacity and the following climatic parameters values: moisture, temperature and wind. Used particularly in Europe (Germany, Russia, Poland), this index was modified by Li and Chan (2000) in order to be used in Asia at Honk Kong. Siple and Passel (1945) [21] introduced an index that evaluates the effect of wind in cold environments, called "wind-chill index" (WCI) which was determined experimentally in wind tunnels. In 1974 Becancenot [1] bring a modification to this index by 
establishing an equation based on air temperature and wind speed measured at a high of $2 \mathrm{~m}$ above land surface. In North America a variant of this index based on air temperature and wind speed at $10 \mathrm{~m}$ was used until 2001 when, The US National Weather Service together with The Environment Agency of Canada changed it with another index variant so called "wind chill equivalent temperature" (WCET). An index used in all types of climate is the one determined by Sharla (1950). Yaglou and Minard (1957) [27] establish a heat stress index called wet-bulb globe temperature (WBGT) which was based on the determination of two variables: wet-bulb temperature (combined with dry-bulb temperature indicates humidity) and globe thermometer temperature (measured with a globe thermometer, also known as a black globe thermometer). Both types of instruments are less used, especially in automated weather stations, the latter index being also very expensive. For this reason, the use of the index is limited. Because it is recommended by ISO 7243 the countries of excessively hot climates and under the influence of Great Britain use a simplified formula for determining the heat stress index that takes into account the pressure (tension) of air vapor and temperature, moreover there is a scale of values available to those who want a quick determination (http://www.bom.gov.au/info/thermal_stress/, 2011). An index often used in urban areas located in excessively warm climates it is HUMIDEX. This index determined by J.M. Masterton and F.A. Richardson (1979) [14] is a regression equation based on the temperature and vapor pressure that quantifies the risk degree of the human body in conditions of excessive temperature and humidity. This index it is used only for temperatures between $20^{\circ} \mathrm{C}$ and $50^{\circ} \mathrm{C}$.

From the category of indexes based on heat balance it is well known PMV index (Predicted mean vote) recommended by ISO 7330 (2005) [28]. PMV index was experimentally determined by Fanger (1970) [6] and it is based on the vote of a group of people introduced in a climatic chamber. The mathematical model determined is quite complex and it is recommended to moderate climate zones.

This short presentation of these indices reveals that in the 90s there was a considerable effort to determine the thermal comfort indices for different types of climates and taking into account as many variables. In 1999, The International Society of Biometeorology had a project that was aimed to determine an universal thermal comfort index (UTCI) based on the most advanced thermo-physiological models. Since 2005 these efforts were strengthened through participation in the COST 730 of an impressive number of physicians, meteorologists, climatologists, computer experts, etc. In 2009 the project was completed and today it features a tool [3] available on the internet that calculates UTCI index.

In Romania are used certain indices, mainly from the category of direct indices, for establishing the tourism potential of different areas from counties such as Suceava County (Teodorescu), Oradea County or Danube Delta and less for establishing the thermal comfort.

The objective of this article is to establish thermal comfort or thermal discomfort conditions of the Dobrogea region. This article is divided into three sections discussing: (i) a presentation of the indices used in determining thermal discomfort, (ii) in the Data and Methodology are presented: the main climatic 
characteristics of the Dobrogea region and the data and methods used in determining thermal discomfort indices. (iii) Section three is dedicated to results and discussion.

\section{DATA AND METHODOLOGY}

Dobrogea region, due to its geographical position, between the lower Danube River and the Black Sea, is situated as well as Bărăgan territory under the influence limit of the Azores Anticyclone and under the influence of the Eurasian continental anticyclones that favor prolonged solar radiation and therefore, the occurrence of climate risk events: drought, aridity, heat waves, etc.

\section{The evolution of Dobrogea's climate}

Dobrogea climate is characterized by the existence of two well individualized climate units [19]:

- A western unit whose extension varies from 20 to $50 \mathrm{~km}$ towards the coast, depending on the hot/cold season of the year. The climate is continental for this unit. In the cold period of the year, being influenced by the Black Sea, the temperature remains positive up to an altitude of $100 \mathrm{~m}$. During the warm season, the climate is influenced by the sea breeze.

- An eastern unit located beyond the $50 \mathrm{~km}$ strip, where thermal inversion regime is emphasized only on the lower lands where the climate is temperate continental

Following a study by the M. A. Abdula in 2010, it is found that the coastal zone of the Danube Delta is bounded by the $11^{\circ} \mathrm{C}$ annual isotherm. In the $1961-2006$ period, the highest annual average temperature values recorded at Sulina were $12.7^{\circ} \mathrm{C}$ (1966), $13.0^{\circ} \mathrm{C}(2000)$ and $13.3^{\circ} \mathrm{C}(2006)$, at Sfantu Gheorghe were $12.7^{\circ} \mathrm{C}(1966)$ and $12.5^{\circ} \mathrm{C}(1999)$. In the $1985-2006$ period, the highest annual average temperature values recorded at Jurilovca were $12.7^{\circ} \mathrm{C}(1999)$ and $13.6^{\circ} \mathrm{C}(2002)$, and at Gura Portiţei were $11.4^{\circ} \mathrm{C}(1998)$ and $12.6^{\circ} \mathrm{C}$ (2006). In another study, conducted over a 41-year period (1965-2005) and for 10 meteorological stations located in the Dobrogea region it was found [12] that the multi-annual average temperatures varies rather limited (approximately $10-12^{\circ} \mathrm{C}$ ), the highest values of the multi-annual average temperatures being recorded at the seaside to Constanţa $\left(11.7^{\circ} \mathrm{C}\right)$, Mangalia $\left(11.6^{\circ} \mathrm{C}\right)$ and Sulina $\left(11,5^{\circ} \mathrm{C}\right.$ - situated at $3 \mathrm{~km}$ wide from Sulina branch). The situation presented in the map of Fig. 1 shows that temperatures decrease from the east (from seaside) and from the west (from the Danube) to the inside of Dobrogea territory. The same situation is presented by Paltineanu Cr., Et al. 2000 [19], which states that the annual isotherms decreases from coastal area to the interior, the higher values of over $11^{\circ} \mathrm{C}$ being recorded in the littoral strip, on a larger area in the South Dobrogea, in the Danube Delta and on a smaller area in Central Dobrogea.

As regards the precipitation, their values are the lowest from the entire country. They grow unevenly from the coast towards the interior of Dobrogea area, the izohyetes tending to become parallel to the shore [19]. Izohyetes values increase from about $260 \mathrm{~mm}$ at Sulina to about $462 \mathrm{~mm}$ at Tulcea [13]. Multiannual precipitation 
values are $262 \mathrm{~mm}$ at the seaside (Sulina), $423 \mathrm{~mm}$ at Constanta and $427 \mathrm{~mm}$ at Mangalia.
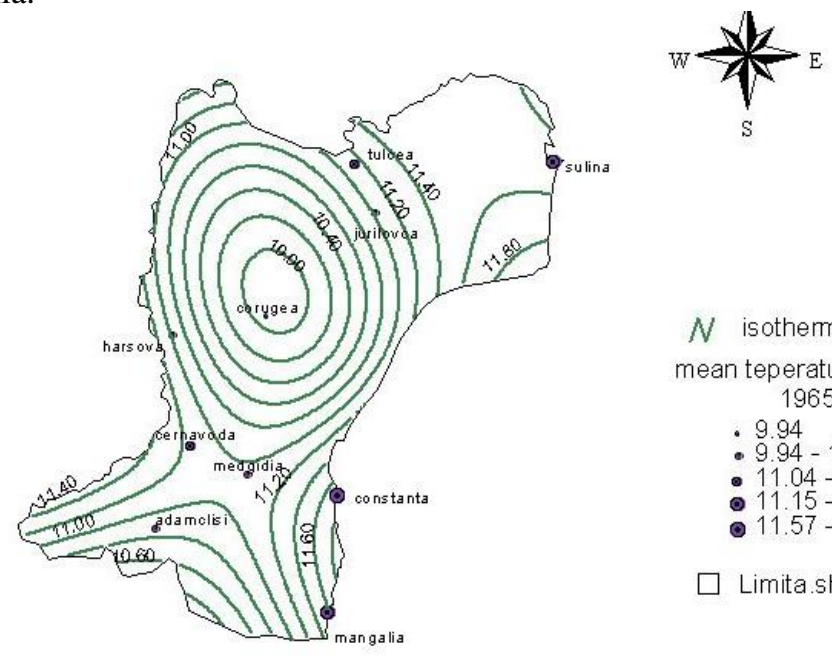

$N$ isotherms

mean teperature from station

1965-2005

- 9.94

- $9.94-11.04$

- $11.04-11.15$

- $11.15-11.57$

$11.57-11.74$

Limita.shp

Fig. 1. The territorial distribution of temperatures in Dobrogea [12]

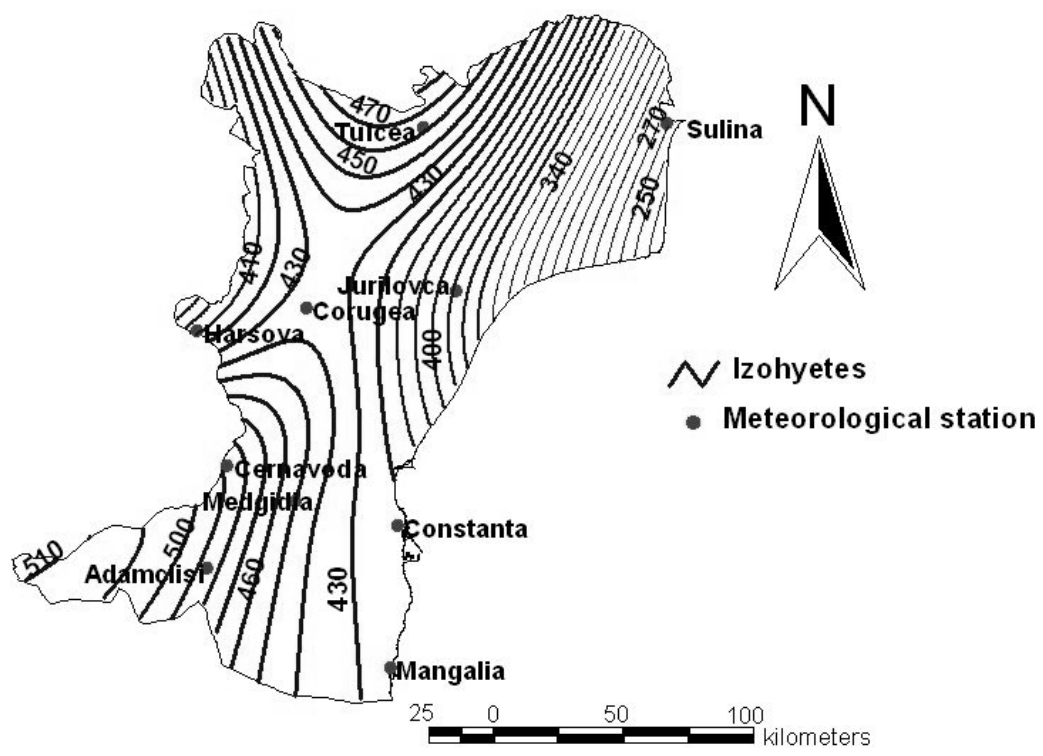

Fig. 2. The territorial distribution of precipitation [13] 
In the maritime area of the Danube Delta, where the water surfaces prevail, and where the ascending convective conditions of air are unfavorable, the average annual rainfall amounts are lower than the rest of the Black Sea coast (Abdula MA, 2010): the annual amount is $352 \mathrm{~mm}$ at Sfântu Gheorghe, and $317 \mathrm{~mm}$ at Gura Portiței.

Due to its geographical position as compared with the current barometric atmospheric action (especially the Euro-Siberian anticyclone or Eastern European anticyclone and the Mediterranean Depression), a relatively uniform topography with low altitudes, the proximity of the Black Sea and the Romanian Carpathians layout, Dobrogea deserves the title of "the most wind" region of the country [4]. In the southern section of coastline, the highest frequency of wind belong to the following directions: west $(20.3 \%$ to $17.0 \%$ in Constanta and Mangalia), northwest (15\% and $10.4 \%)$, north in Constanta (13.3\%) and southeast to Mangalia (14.4\%), largely influenced by the general orientation of the Black Sea coast. In the northern coastal area of the Danube Delta, the highest average annual frequencies belong to northern winds.

\section{Data study}

For this study we have available meteorological data on the following climatic variables: air temperature, wind speed, humidity and vapor air pressure for 10 meteorological stations in the territory of Dobrogea (Fig. 3).

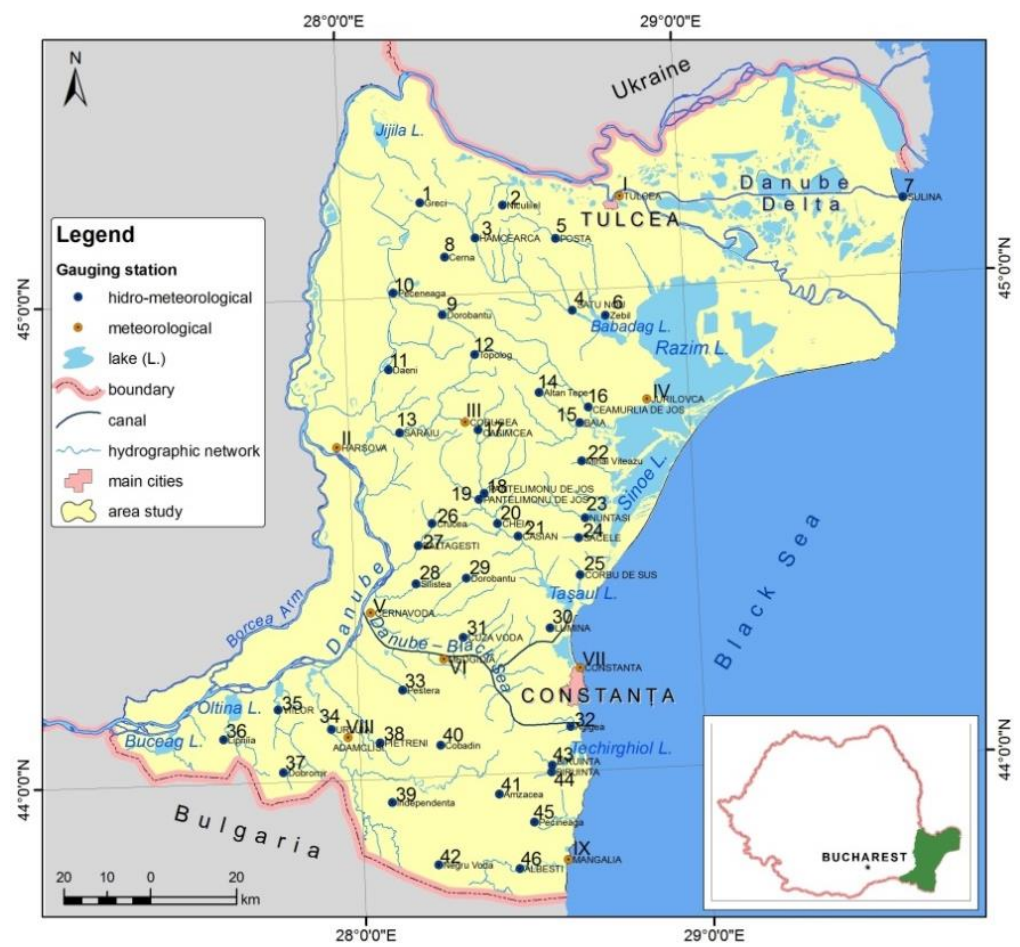

Fig. 3. Distribution of meteorological stations across the Dobrogea territory 
Ovidius University Annals Series: Civil Engineering, Issue19, $2017 \quad 93$

We have the temperatures data for 10 stations during 1965-2005. For other climatic variables, the values are recorded during the period 1990-2005, except for stations: Harsova, Constanta, Mangalia, Tulcea, Sulina and Jurilovca, where the records are for the period 1965-2005. For this reason we consider only the stations from the coast and from the Danube Delta where we have series of values recorded over the same period.

Following the annual average temperature variation from 10 meteorological stations [12] there is a sequence of hot / cold periods, with an increase over the annual average temperature since 1997 (Fig. 4). The lowest values are recorded at Jurilovca, the highest values are recorded in southern coastline (Constanta and Mangalia) and decreased in the northern coast. Applying several statistical tests to detect the break in time series (Pettit, CUSUM, Hubert, Lee \& Heghinian, Buishand) we found (at all stations analyzed - table no. 1.) an increase with $0,8^{\circ} \mathrm{C}$ in temperature since 1997 . The value obtained are in accordance with the values estimated for Europe. In this situation we suspect that thermal discomfort value is increasing after the year 1997.

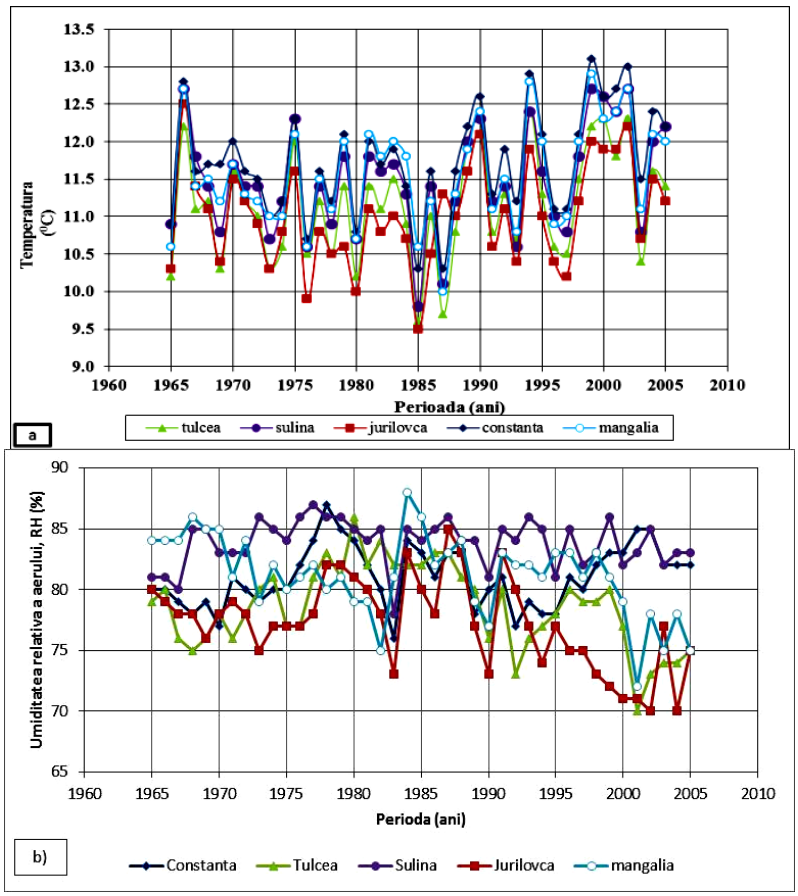






Fig. 4. The evolution of the climate variables in the 1965-2005 period; a) - temperature; b) humidity; c) vapor pressure; d) wind speed at $2 \mathrm{~m}$.

Table no. 1. Annual average values of temperature on the coast, before and after the break tests.

\begin{tabular}{|l|c|c|c|c|c|}
\hline & Tulcea & Sulina & Jurilovca & Constanta & Mangalia \\
\hline Multiannual average 1965- 2005 & 11.14 & 11.49 & 11.01 & 11.74 & 11.57 \\
\hline Year of series change & 1997 & 1997 & 1997 & 1997 & 1997 \\
\hline Multiannual average 1965-1997 & 11.03 & 11.35 & 10.90 & 11.59 & 11.43 \\
\hline Multiannual average 1997-2005 & 11.56 & 12.00 & 11.42 & 12.30 & 12.06 \\
\hline
\end{tabular}

Humidity has the highest values at Sulina. In fact all the other climate variables values (vapor pressure and wind speed) are higher in Sulina. For Constanta meteorological station, air humidity values are increasing, while for the other stations: Tulcea, Jurilovca and Mangalia air humidity values are decreasing (Fig. 4b). The wind speed (Fig. 4d) is decreasing for all five stations studied. For other variables, except for temperature, we didn't test time series to detect the existence of breaks in the time series.

For calculations has been used multiannual average monthly values.

\section{Methodology}

In order to study the thermal discomfort we used models from those classified as direct and applicable for moderate or hot climates. 
Ovidius University Annals Series: Civil Engineering, Issue19, $2017 \quad 95$

Thom's thermal discomfort index [24] is calculated with the following formula:

$$
\mathrm{DI}\left({ }^{\circ} \mathrm{C}\right)=0,4 \cdot\left(\mathrm{t}_{\mathrm{d}}+\mathrm{t}_{\mathrm{w}}\right)+4,8 \text {, where }
$$

$t_{d}$ - is the air temperature measured at the dry bulb $\left({ }^{\circ} \mathrm{C}\right)$

$\mathrm{t}_{\mathrm{w}}-$ is the air temperature measured at wet thermometer $\left({ }^{\circ} \mathrm{C}\right)$

Because wet bulb temperature is quite difficult to be determined, Bellofiore R. et.al, (2005) established a relationship between the relative humidity (RH) and temperature measured at the wet thermometer $\left(\mathrm{t}_{\mathrm{w}}\right)$ given by the equation:

$$
\mathrm{RH}=98-5 \cdot\left(\mathrm{t}_{\mathrm{d}}+\mathrm{t}_{\mathrm{w}}\right)
$$

Thom's formula becomes: DI=0,8 $\mathrm{t}+0,08 \mathrm{RH}-3,04$.

Results interpretation is presented in Table no.2.

Table no. 2. Thermal discomfort conditions [24]

\begin{tabular}{|l|l|}
\hline Discomfort conditions & $\mathrm{DI}\left({ }^{\circ} \mathrm{C}\right)$ \\
\hline No thermal discomfort & $<21$ \\
\hline Under 50\% of population feels discomfort & $21-24$ \\
\hline Over 50\% of population feels discomfort & $25-27$ \\
\hline Most of population suffers discomfort & $28-29$ \\
\hline Everyone feels stress & $30-32$ \\
\hline State of medical emergency & $>32$ \\
\hline
\end{tabular}

Thom index was calculated by Kyle (1994) [9], Unger (1999) [26], Toy et.al., 2007 [25] with the following equation and the index so calculated is called the temperature - humidity index (THI):

$$
\mathrm{THI}\left({ }^{\circ} \mathrm{C}\right)=\mathrm{t}-(0,55-0,0055 \cdot \mathrm{RH})(\mathrm{t}-14,5), \text { where: }
$$

$\mathrm{t}$ - is air temperature $\left({ }^{\circ} \mathrm{C}\right)$

$\mathrm{RH}$ - is air relative humidity $(\%)$

The thresholds values [9] are shown in the table below (table no. 3).

Table no. 3 THI rating scale

\begin{tabular}{|l|l|l|l|}
\hline THI index $\left({ }^{\circ} \mathrm{C}\right)$ & Conditions & THI index $\left({ }^{\circ} \mathrm{C}\right)$ & Conditions \\
\hline$<-40$ & Extreme cold & $+13 \div 15$ & Low cold \\
\hline$-40 \div-20$ & Very high cold & $15 \div 20$ & No discomfort \\
\hline$-10 \div-1.8$ & High cold & $20 \div 26.5$ & Hot \\
\hline$-1.8 \div+13$ & Moderate cold & $26.5 \div 30$ & Very hot \\
\hline & & $>30$ & Extreme hot \\
\hline
\end{tabular}


In INMH version (formerly National Institute of Meteorology and Hydrology), this index is calculated with the following equation:

$\operatorname{IUT}\left({ }^{\circ} \mathrm{C}\right)=(\mathrm{t} \cdot 1,8+32)-(0,55-0,0055 \cdot \mathrm{RH}) \cdot[(\mathrm{t} \cdot 1.8+32)-58]$, where the notations are as above.

Depending on the values obtained can be set the following thresholds: $\leq 65-$ state of comfort; 66 - 79 - state of alert; $\geq 80$ - discomfort (Voicu, 2011).

Effective temperature index (TEE) modified by Gregorczuk (1968) [7] which take account of the the effect of wind is calculated by the relationship:

$$
T E E=37-\frac{37-t}{0.68-0.0014 \cdot R H+\frac{1}{1.76+1.4 \cdot v^{0.75}}}-0.29 \cdot t(1-0.01 \cdot R H), \text { where }
$$

$\mathrm{v}$ - is wind speed $(\mathrm{m} / \mathrm{s})$.

This index rating scales varies within wide limits depending on the latitude, as follows: 14.4 to $20,6^{0}$ TEE - UK; 16.7 to $21.8^{0}$ TEE - Yakovenko region of the Russian Federation; $18-22^{0}$ TEE - U.S.A.; 23.3 -29.4 TEE - tropical countries [23].

\section{RESULTS AND DISCUSSION}

The following figures (Figure 5) shows the values of the four indices calculated for the coastal zone of the Black Sea.

We remind you that values of these indices were calculated based on multiannual monthly averages climatic variables entering into account.

The analysis performed for the 5 stations located on the coastline and illustrated in the graph in Figure 5 shows the following: (i) all provide clues about the same assessment, namely that the period of discomfort is installed especially in hot periods of the year (July and August); (ii) TEE and THI index values (Fig. 5b and 5d) indicates discomfort (upon cooling) about the periods from January to May and October to December.

As we mentioned in Section 2.2. the temperature after 1997 has increased by about $0,8^{\circ} \mathrm{C}$. Considering this result and calculating the annual average monthly temperature for 1998-2005 period, the index values increase by one unit, so June is on the borderline between comfort and discomfort.

From this study the following conclusions can be drawn: (i) the mathematical models used to determine the thermal discomfort caused by climatic factors are easily calculated and interpreted; (ii) TEE was chosen, because this index takes into account all climatic variables, but has a rating scale which is not adapted for Romania; (iii) values calculated for each thermal discomfort index does not show a clear spatial variability; (iv) if the temperature will increase in the next period as stipulated all reports of the specialized organisms, surely June and September will enter in the area of discomfort. 




a) $\rightarrow$ Sulina $\rightarrow$ Constanta $\rightarrow$ - Jurilovca $\multimap$ Mangalia $\rightarrow$ Tulcea

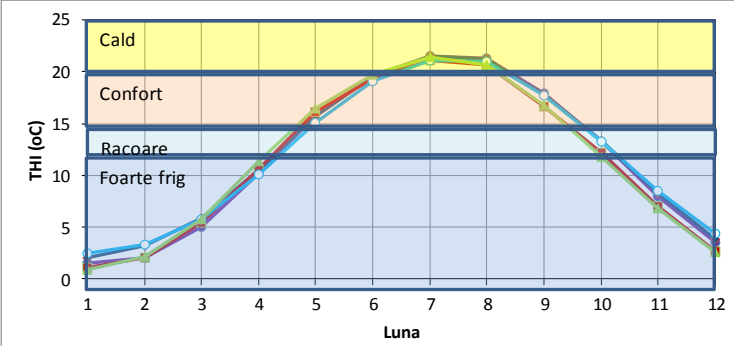

b) $\rightarrow$ Sulina $\rightarrow$ Constanta $\rightarrow-$ Jurilovca $\rightarrow$ Mangalia $\rightarrow$ Tulcea



c) $\rightarrow$ Sulina $\rightarrow$ Constanta $-\backsim$-Jurilovca $\longrightarrow$ - Mangalia $\rightarrow$ Tulcea

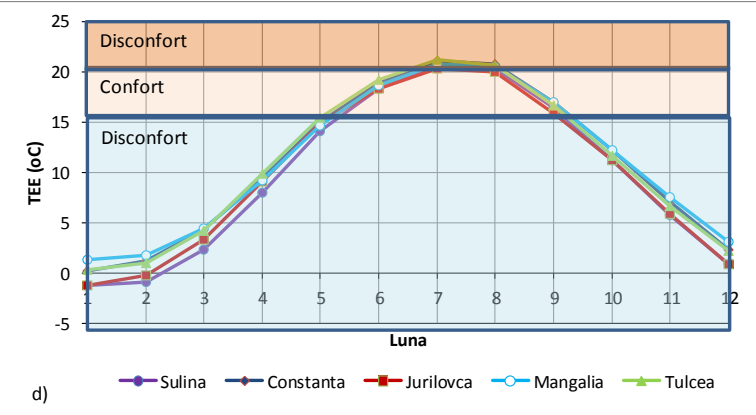

Fig. 5. Discomfort index values (1965-2005): a) DI; b) THI; c) IUT; d) TEE 
98 Ovidius University Annals Series: Civil Engineering, Issue19, 2017

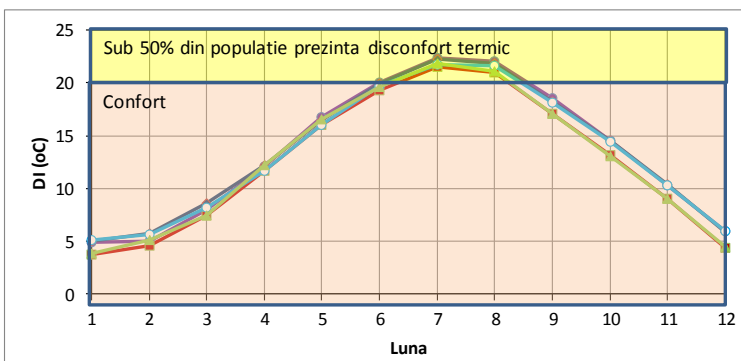

a) $\quad \rightarrow-$ Sulina $\rightarrow$ Constanta $\rightarrow$ - Jurilovca $\rightarrow$ Mangalia $\longrightarrow$ Tulcea

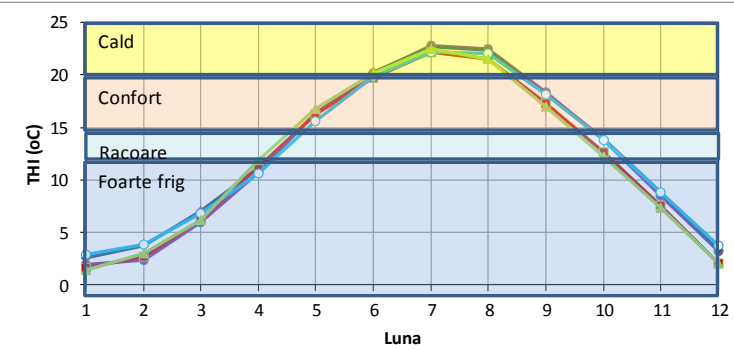

b) $\rightarrow$ Sulina $\rightarrow$ Constanta $\rightarrow$ Jurilovca $\rightarrow$ Mangalia $\rightarrow$ Tulcea

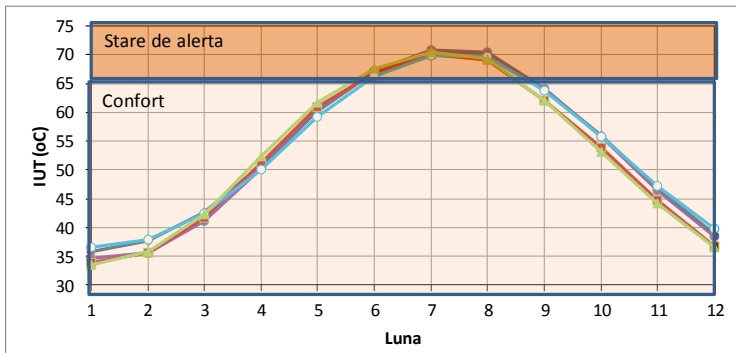

c) $\rightarrow-$ Sulina $\rightarrow$ Constanta $\rightarrow-$ Jurilovca $\rightarrow$ Mangalia $\rightarrow$ Tulcea

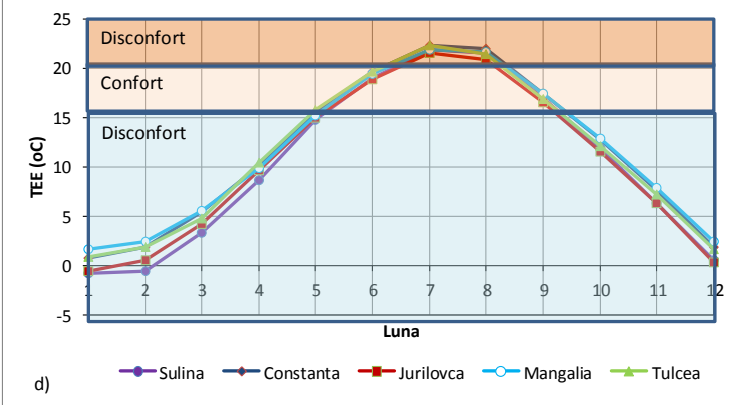

Fig. 6. Discomfort index values (1998-2005): a) DI; b) THI; c) IUT; d) TEE 
As a perspective, we propose: (i) determination of these indices for other meteorological stations in Dobrogea; (ii) the correlation of these indices with parameters such as heart rate, body temperature and other physiological variables.

Without a doubt the development of an early warning system based on one of these indices it is necessary.

\section{REFERENCES}

[1] Bécancenot J.P. Premières données sur les stress bioclimatiques moyens en France, Annal. Géogr., p. 459, 1974

[2] Belding HS, Hatch TJ Index for evaluating heat stress in terms of resulting physiological strain. Heating, Piping and Air Conditioning 27, 129-36, 1955

[3] Blazejczyk K, et al. Comparison of UTCI to selected thermal indices. International journal of biometeorology 56(3):515-535, 2012

[4] Ciulache, S., Torică, V. Clima Dobrogei, Analele Universitătii Bucuresti, anul LII, 2003

[5] D'Ambrosio Alfano F.R., et. al. Thermal environment assessment reliability using temperature--humidity indices. Industrial Health, January 2011, 49, pp.95-106, DOI:10.2486/indhealth.MS1097

[6] Fanger P.O., Thermal comfort, 1st. Ed. McGraw-Hill Book Co, NewYork, p. 244, 1970

[7] Gregorczuk M., Bioclimates of the world related to air enthalpy International Journal of Biometeorology, January 1968, Volume 12, Issue 1, pp 35-39

[8] Hill L, Griffith OW, Flack M. The measurement of the rate of heat loss at body temperature by convection, radiation and evaporation. Phil Trans R Soc (B); 207:183220. doi: $10.1098 /$ rstb. $1916.0005,1916$

[9] Kyle WJ The human bioclimate of Hong Kong. In: Proceedings of the Contemporary Climatology Conference, Brno, Brazdil R, Kolár` M (Eds.), 345-50, Tisk Litera, Brno, 1994

[10] Krzysztof Błażejczyk, Gerd Jendritzky, Peter Bröd, Dusan Fiala, George Havenith, Yoram Epstein, Agnieszka Psikuta, Bernhard Kampmann, An introduction to the universal thermal climate index (utci), 2013

[11] Li PW, Chan ST. Application of a weather stress index for alerting the public to stressful weather in Hong Kong. Meteorol Appl., 7:369-375. doi: 10.1017/S1350482700001602, 2000

[12] Maftei C. \& Bărbulescu A. (2008) Statistical analysis of climate evolution in Dobrudja region. In Proceedings of the World Congress on Engineering, London, UK [13] Maftei C., Bărbulescu A., Buta C., Serban C., Change Points Detection and Variability Analysis of some Precipitation Series, Recent Researches in Computational Techniques, Non-Linear Systems and Control, July 2011, ISBN 978 1-61804-011-4, July 2011, pp. 232 - 237

[14] Masterton, J.M. and F.A. Richardson 1979: Humidex: A method of quantifying human discomfort due to excessive heat and humidity. CLI 1-79, Environment Canada, Downsview, Ontario 
[15] Missenard FA, Température effective d'une atmosphere Généralisation température résultante d'un milieu. In: Encyclopédie Industrielle et Commerciale, Etude physiologique et technique de la ventilation. Librerie de l'Enseignement Technique, Paris, pp 131-185, 1933

[16] Nastos, P.T., Matzarakis, A., 2006. Weather impacts on respiratory infections in Athens, Greece. Int. J. Biometeorol. 50:358-369

[17] NIOSH, Criteria for a recommended standard: occupational exposure to hot environment, National Institute for Occupational Safety and Health, 101-110, DHHS (NIOSH) Publication No 86-113, Washington DC, 1986

[18] Parsons KC., Human thermal environments: the effects of hot, moderate, and cold environments on human health, comfort and performance. Taylor \& Francis. New York: London; p. 527, 2003

[19] Paltineanu Cr. et al., Dobrogea, condițiile pedoclimatice, consumul și necesarul apei de irigație ale principalelor culturi agricole. Editura Ex Ponto, Constanța, 258 pp, 2000 a

[20] Robine et al., Death toll exceeded 70,000 in Europe during the summer of 2003,

C R Biol. 2008 Feb;331(2):171-8. doi: 10.1016/j.crvi.2007.12.001. Epub 2007 Dec 31

[21] Siple, P., Passel, C.F., 1945. Measurements of dry atmospheric cooling in subfreezing temperatures. Proc Am PhilosSoc 89:177-199

[22] Steadman R. G., A universal scale of apparent temperature, J. Clim. Appl. Meteor., p. 1674-1687, 1984

[23] Teodoreanu E. \& Bunescu I. Thermal Comfort. Present Environment and Sustainable Development. University “Al. I. Cuza” Iași. 1: p 135-142, 2007

[24] Thom, E.C. The discomfort index. Weather wise, 12: 57-60, 1959

[25] Toy S., et al. Determination of bioclimatic comfort in three different land uses in the cityof Erzurum, Building and Enviroment, p. 1315-1318, Turky, 2007

[26] Unger J., Comparisions of urban and rural bioclimatological conditions in the case of a Central-European city, Int.J. Biometeorology, p. 139-144, 1999

[27] Yaglou C.P., Minard, D., Control of heat casualties at military training centers. Am MED Assoc Arch IND Health 16:302-316, 1957

[28] ISO 7730: Moderate thermal environments- Determination of the PVI and PPD indices and specification of the conditions of thermal comfort. International Organization of Standardization, Geneva, 1983 